\title{
Benefits and Critical Knowledge Gaps in Determining the Role of Floating Photovoltaics in the Energy-Water-Food Nexus
}

\author{
Sika Gadzanku ${ }^{1, *}$, Heather Mirletz ${ }^{1,2} \oplus$, Nathan Lee ${ }^{1}\left({ }\right.$, Jennifer Daw ${ }^{1}$ and Adam Warren ${ }^{1,2}$ \\ 1 National Renewable Energy Laboratory, Golden, CO 80401, USA; heather.mirletz@nrel.gov (H.M.); \\ nathan.lee@nrel.gov (N.L.); jennifer.daw@nrel.gov (J.D.); adam.warren@nrel.gov (A.W.) \\ 2 Advanced Energy Systems, Colorado School of Mines, Golden, CO 80401, USA \\ * Correspondence: sika.gadzanku@nrel.gov
}

Citation: Gadzanku, S.; Mirletz, H.; Lee, N.; Daw, J.; Warren, A. Benefits and Critical Knowledge Gaps in Determining the Role of Floating Photovoltaics in the

Energy-Water-Food Nexus.

Sustainability 2021, 13, 4317.

https://doi.org/10.3390/su13084317

Academic Editor: Tamer Khatib

Received: 5 March 2021

Accepted: 7 April 2021

Published: 13 April 2021

Publisher's Note: MDPI stays neutral with regard to jurisdictional claims in published maps and institutional affiliations.

Copyright: (c) 2021 by the authors. Licensee MDPI, Basel, Switzerland. This article is an open access article distributed under the terms and conditions of the Creative Commons Attribution (CC BY) license (https:// creativecommons.org/licenses/by/ $4.0 /)$.

\begin{abstract}
Floating solar photovoltaic (FPV) systems have become an increasingly attractive application of photovoltaics (PV) because of land-use constraints, the cost of land and site preparation, and the perceived energy and environmental co-benefits. Despite the increasing interest in FPV systems, a robust validation of their suggested co-benefits and impacts on the nexus of energy, water, and food (EWF) systems is lacking. This information gap makes it challenging for decision makers to justify its adoption-potentially suppressing FPV deployment. To address this gap and to help de-risk this PV deployment opportunity, we (1) review the suggested co-benefits of FPV systems with a focus on the impacts that could alleviate pressures on EWF systems and (2) identify areas where further research is needed to reduce uncertainty around FPV system performance. Our review reveals that EWF nexus-relevant co-benefits, such as improved panel efficiency and reduced land usage, are corroborated in the literature, whereas others, such as water quality impacts, lack empirical evidence. Our findings indicate that further research is needed to quantify the water-related and broader economic, environmental, social, sustainability, justice, and resilience co-benefits and impacts of FPV systems.
\end{abstract}

Keywords: floating solar; FPV; photovoltaics; renewable energy; water security; food security; energy-water-food nexus; co-benefits; impacts

\section{Introduction}

The energy-water-food (EWF) nexus refers to the interconnected nature of these systems where demands have the potential to impact another. Efforts to meet energy, water, and food demands have historically been siloed despite the strong interdependence of these resources [1-3]. Trends such as population growth, urbanization, and climate change have highlighted the importance of considering the competing demands for EWF resources, drawing awareness to the need for more holistic approaches to sustainably meet global demands [1-5]. Figure 1 highlights the interdependence and some competing uses of energy, water, and food and land resources as they relate to the environmental, social, and economic attributes commonly associated with sustainability.

Beyond water's importance to global ecosystems, its role is extensive-spanning irrigation, drinking water, sanitation, power generation, recreation, ecosystems, and industrial uses. Global water demand by sector in 2014 was estimated at $10 \%$ for power generation and primary energy production, $7.5 \%$ for industry, 15\% for municipal use (such as drinking water and recreation), and approximately $68 \%$ for agricultural use [6-8]. As population increases, so does the demand for water. Global aggregate water use for power generation, food production, and industrial and domestic use is projected to increase by 20-30\% during the next 30 years, raising concerns about the security of these resources due to competing demands [6]. Water is also vulnerable to climate change impacts, which affect the timing and intensity of precipitation (e.g., increased occurrence and intensity of floods and/or droughts), the availability of freshwater supplies, and water quality. The 
world's power supply is still dominated by thermoelectric (fossil-fuel-based and nuclear) and hydroelectric power plants, which require a reliable supply of water [9,10]. Climate change impacts on water availability and water quality can leave these power generation systems as stranded infrastructure, leading to reduced electricity capacity availability and increased brownouts [11-14]. Continued dependence on water resources for power generation could exacerbate existing water stresses, leaving global power systems vulnerable to changes in water resource availability $[9,15]$. For example, the increased occurrence and intensity of droughts due to climate change and existing water stresses caused by the competing demands for water can lead to less water available for hydropower generation, leading to the need for brownouts and costly energy imports. Resilience planning for potential changes in water supply through energy technology selection, energy storage, and system operations as part of the energy system planning process could help alleviate these risks. The increased adoption of renewable energy, energy-efficiency measures, the reoptimization of hydropower and thermoelectric plant operations, and the wide deployment of water-saving technologies in electricity production could help offset these vulnerabilities, and balance the resulting impacts on water use for other applications $[9,11,16-18]$.

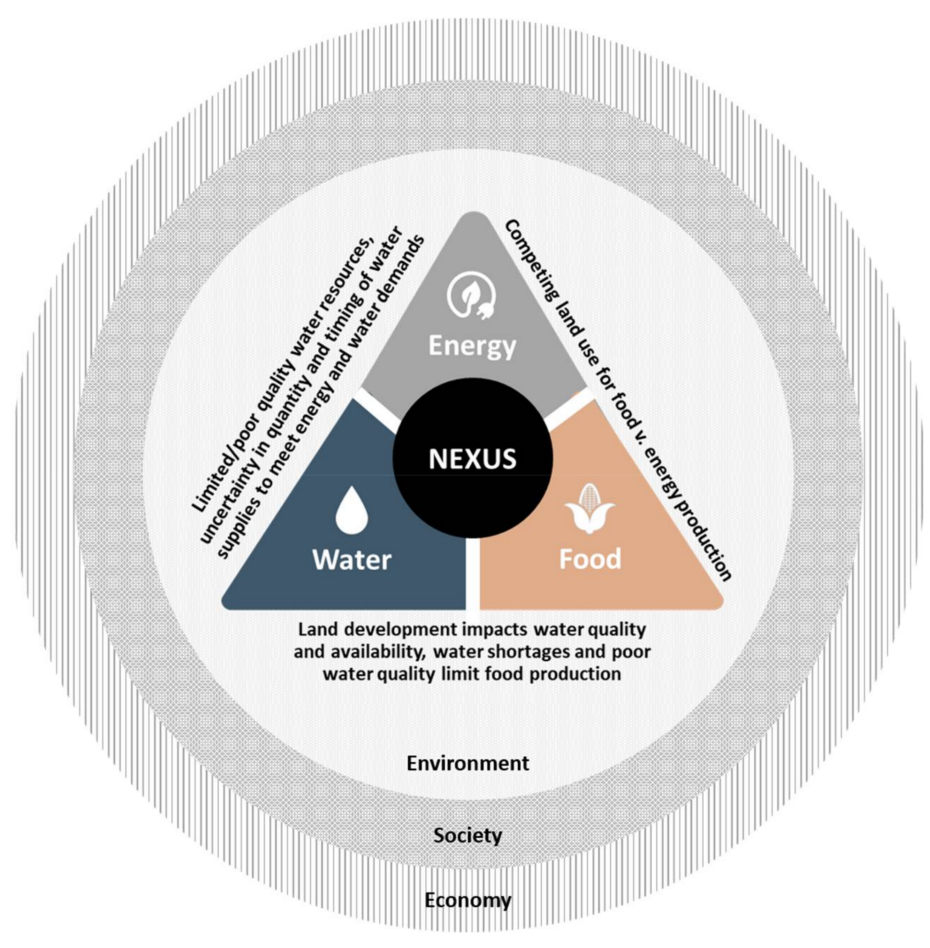

Figure 1. Overview of competing uses for energy, water, food and land resources.

As populations grow, the demand for housing, food, and energy also increases, creating land use competition for buildings, industry, food production, power generation, transportation, fuel production, and ecosystem goods and services [19-21]. Global energy demand is projected to increase from $25-50 \%$ by 2050, led by growth in Asia, South America, and Africa [22]. These anticipated increases in energy demand will further strain existing land resources. Trainor et al. [23] estimated that by 2040 , more than $800,000 \mathrm{~km}^{2}$ (an area greater than the state of Texas) of additional land in the United States will be impacted by energy development. In Europe, Trondle [24] estimates that approximately 2\% of Europe's total land mass-approximately the size of Portugal — would be needed to cost-optimally transition to a $100 \%$ renewable electricity mix. In general, renewable energy projects have a higher land footprint (ranging from 1-10 $\mathrm{m}^{2} / \mathrm{MWh}$ for non-bioenergy renewable energy and 100-1000 $\mathrm{m}^{2} / \mathrm{MWh}$ for bioenergy) than fossil fuel projects (which range from $0.1-1 \mathrm{~m}^{2} / \mathrm{MWh}$ ) [25]. Fossil-fuel based and nuclear generation projects, however, typically require new land once all the energy resources have been extracted, whereas renewable 
energy projects can typically reuse the same land $[23,26]$. Competition for land is especially acute in land-constrained countries such as islands [27]. Alternative power generation options that have low or no land-use requirements could help alleviate this pressure on the energy-land nexus. For example, Hoffacker et al. [28] explored the potential for solar energy development on nonconventional land-cover types, including reservoirs, to mitigate land scarcity concerns. Research is also being conducted on the colocation of photovoltaics (PV) with agricultural and grazing lands and the colocation of PV on degraded land, such as landfills $[29,30]$. There is a need to identify innovative technology and policy solutions that make the best use of land resources to sustainably meet the interdependent demands for energy, water, food, and land.

Floating solar photovoltaic (FPV) systems have emerged as a potential technological solution to meet future energy demands while reducing some of the highlighted pressures on land and water resources. As such, power sector stakeholders in land-constrained countries (several of which are located in Asia) have displayed strong interest in this PV deployment opportunity (more than $80 \%$ of installed FPV projects are located in Asia, largely in China, Korea, and Japan) [31]. Cazzaniga and Rosa-Clot [32] project that FPV system interest and growth could continue, potentially contributing up to $1.9 \%$ (710 TWh) of total global electricity production by 2030. Stand-alone (Figure 2) and hybridized FPV systems are an application of PV technology where panels are sited on water rather than installed on land or a rooftop. Beyond generating energy from a renewable source, FPV is an attractive option because of its perceived co-benefits-benefits beyond renewable energy generation. These extensive potential co-benefits are listed in Table 1 [33-42]. Ranjbaran et al. [43] present a thorough review of the applications of FPV systems, cited co-benefits, and comparisons with ground-mounted PV. Hybridizing FPV systems with hydropower dams could unlock additional co-benefits, including decreased infrastructure installation costs by leveraging the existing transmission infrastructure, reduced curtailment and improved power quality of $\mathrm{PV}$, decreased dependence on basin water for power generation especially during droughts and other water scarcity periods, and reduced erosion from the diminished wave action in reservoirs [31,34,44-49]. Sanchez et al. [50] estimate that siting FPV systems on 1\% of the existing hydropower reservoirs in Africa could generate approximately 53 TWh of electricity (largely from FPV plants located in West and East Africa, which have abundant hydropower and solar resources). Lee et al. [49] estimate that the global technical potential for FPV-hydropower hybrids ranges from 4251 to 10,616 TWh (which could meet $29-72 \%$ of additional power generation needs by 2040).

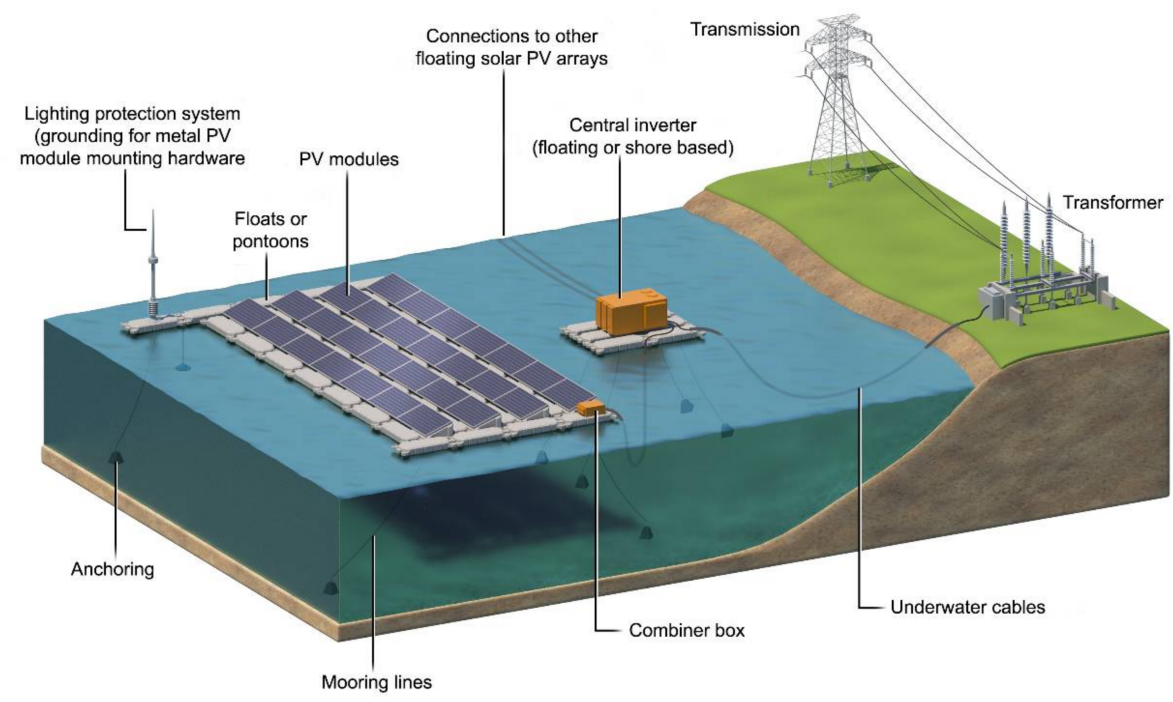

Figure 2. Schematic of a typical large-scale floating photovoltaic (FPV) system. Reprinted with permission from ref. [49]. Copyright 2021 Elsevier. 
Table 1. List of standalone $(\mathrm{S})$ and hybridized $(\mathrm{H}) \mathrm{FPV}$ co-benefits reviewed in this paper $(\mathrm{S}=$ standalone $\mathrm{FPV}, \mathrm{H}=\mathrm{hybridized}$ FPV) [33-42,49].

\begin{tabular}{|c|c|c|c|c|}
\hline Social & Economic & Energy & Water & Food or Land \\
\hline Reduces land use $(\mathrm{S}, \mathrm{H})$ & $\begin{array}{l}\text { Increases ease of } \\
\text { installation }(\mathrm{S}, \mathrm{H})\end{array}$ & $\begin{array}{l}\text { Increases panel } \\
\text { efficiency }(S)\end{array}$ & Reduces evaporation $(\mathrm{S}, \mathrm{H})$ & Reduces land use $(\mathrm{S}, \mathrm{H})$ \\
\hline $\begin{array}{c}\text { Repurposes otherwise } \\
\text { unusable land }(\mathrm{S}, \mathrm{H})\end{array}$ & $\begin{array}{l}\text { Reduces site preparation } \\
(\mathrm{S}, \mathrm{H})\end{array}$ & $\begin{array}{c}\text { Increases panel } \\
\text { packing density }(\mathrm{S}, \mathrm{H})\end{array}$ & $\begin{array}{l}\text { Reduces algae growth and } \\
\text { improves water quality }(\mathrm{S}, \mathrm{H})\end{array}$ & $\begin{array}{l}\text { Repurposes otherwise } \\
\text { unusable land }(\mathrm{S}, \mathrm{H})\end{array}$ \\
\hline $\begin{array}{l}\text { Preserves valuable land } \\
\text { and water for other uses } \\
(\mathrm{S}, \mathrm{H})\end{array}$ & Modular (S, H) & $\begin{array}{l}\text { Reduces shading } \\
\qquad(\mathrm{S}, \mathrm{H})\end{array}$ & $\begin{array}{l}\text { Reduces water temperature } \\
\qquad(\mathrm{S}, \mathrm{H})\end{array}$ & $\begin{array}{c}\text { Increases energy sources } \\
\text { near demand or } \\
\text { population centers }(\mathrm{S}, \mathrm{H})\end{array}$ \\
\hline $\begin{array}{c}\text { Avoids or reduces } \\
\text { conflicts over land and } \\
\text { water use }(\mathrm{S}, \mathrm{H})\end{array}$ & $\begin{array}{l}\text { Uses existing electrical } \\
\text { transmission } \\
\text { infrastructure }(\mathrm{S}, \mathrm{H})\end{array}$ & $\begin{array}{l}\text { Increases panel } \\
\text { efficiency }(\mathrm{H})\end{array}$ & $\begin{array}{l}\text { Provides power during } \\
\text { drought }(\mathrm{H})\end{array}$ & \\
\hline $\begin{array}{c}\text { Reduces or avoids } \\
\text { power-generation related } \\
\text { air-pollution }(\mathrm{S}, \mathrm{H})\end{array}$ & Reduces curtailment (H) & $\begin{array}{l}\text { Improves power } \\
\text { quality }(\mathrm{H})\end{array}$ & Reduces wave formation $(\mathrm{S}, \mathrm{H})$ & \\
\hline $\begin{array}{l}\text { Reduces displacement of } \\
\text { local communities for } \\
\text { energy development }(\mathrm{S}, \mathrm{H})\end{array}$ & $\begin{array}{l}\text { Improves power } \\
\text { quality }(\mathrm{H})\end{array}$ & & & \\
\hline $\begin{array}{l}\text { Improves power sector } \\
\text { resilience }(\mathrm{S}, \mathrm{H})\end{array}$ & Extends system life (S, H) & & & \\
\hline
\end{tabular}

Understanding the full scope of FPV co-benefits and impacts—social, environmental, economic, and otherwise-will help quantify FPV's potential to ease competing demands on EWF systems; however, there is limited research on this topic and limited research validating the suggested co-benefits of FPV systems and the potential synergies between FPV systems and the EWF nexus. The few papers discussed here represent most of the publicly available research on the potential synergies between FPV systems and the EWF nexus.

Cagle et al. [51] develop an empirical framework and metrics for understanding and measuring land and water resource use for FPV systems. Based on data from four small FPV installations in the United States, the authors find that the FPV systems have a smaller land use footprint than a comparable ground-mounted PV system. On the other hand, these four installations have, on average, a similar or slightly greater resource efficiency than comparable land-based PV and wind power plants. Campana et al. [52] examine how the reduced evaporation from FPV installations could reduce water-energy concerns. The authors develop a techno-economic simulation and optimization model that demonstrated reduced evaporation losses and reduced environmental impacts of shrimp farming. Gamarra and Ronk [53] discuss how FPV deployment could reduce evaporation, reduce water use, and improve water quality in water-scarce Texas through the energy-water lens. Hernandez et al. [54] note that FPV systems can help alleviate land use concerns because FPV systems can be sited on otherwise unusable water bodies while reducing the need for land use in power generation. Pringle et al. [41] discuss potential nexus synergies between FPV deployment and aquaculture to reduce EWF nexus pressures. Some potential benefits highlighted include increased energy output from the PV panels, reduced water evaporation, and improved fish growth rates. Santafé et al. [55] explore potential applications of FPV systems on irrigation reservoirs in Spain to reduce water evaporation and to generate power. Sulaeman et al. [56] evaluate the potential for FPV deployed on hydropower in the Amazon region of Brazil to minimize environmental and social impacts of continued hydropower dam expansion, and Zhou et al. [57] develop a multi-objective optimization model of an FPV-hydropower hybrid system that is optimized for EWF demand priorities. Studying the Shihmen Reservoir watershed and its EWF systems, the authors demonstrate that their multi-objective model for complementary operation of an FPV-hydropower hybrid could improve water storage (by 13\%), food production (by $13.3 \%$ ), and energy output (by $15.1 \%$ ). 
Despite the several potential co-benefits of FPV systems, there is uncertainty about how levelized costs for FPV compare with land-based PV systems. Although the capital costs of FPV systems vary by location, they remain slightly higher than land-based systems [58]; however, recent installations have reduced operation-and-maintenance $(O$ and $M)$ costs (because of reduced cleaning and land upkeep requirements) and land acquisition-related costs (often no cost for an underused water body area) than their land-based relatives [59]. It is unclear whether the increased capital costs of FPV systems are indicative of these systems' nascence in the PV market; however, advances such as improved anchoring, floating platforms, and deployment practices have reduced the installation costs in recent years and could continue to help FPV reach parity with land-based systems [59]. Additionally, valuation methods to quantify the potential economic and grid operational value of the social, environmental, and resilience benefits of FPV are largely absent.

Knowledge gaps remain on the costs of FPV systems, potential negative impacts, and validation of the regularly highlighted co-benefits. These gaps make it challenging for potential adopters to identify and quantify the actual advantages derived from FPV systems-potentially suppressing FPV system investment $[31,60]$. To explore how FPV systems could help reduce pressures on EWF systems, this article reviews relevant FPV co-benefit and impact literature. Other studies are needed to address the gaps in the literature on FPV costs and environmental impacts. The purposes of this work are to (1) review the suggested co-benefits of FPV systems with a focus on the co-benefits that could alleviate EWF system pressures and to (2) identify areas where further research is needed to reduce uncertainty around FPV systems and to de-risk this PV deployment opportunity. We specifically seek to identify empirical evidence on the cited co-benefits of FPV systems. Understanding the full scope of FPV co-benefits will help to quantify the true cost of FPV by understanding its economic and operational value to the grid and its sustainability and resilience benefits to the environment and society.

We limit the scope of FPV systems, in this review, to those sited on inland water bodies. We do not consider systems hosted on marine or offshore water bodies. Additionally, this paper largely focuses on the co-benefits provided by FPV as there is very limited research available on the potential negative impacts of FPV systems.

\section{Materials and Methods}

The research presented is based on a systematic literature review, specifically seeking empirical evidence (data) on the suggested co-benefits and impacts of FPV systems, both stand-alone and hybridized with hydropower.

First, as illustrated in Figure 3, a broad literature survey was conducted to identify recent research on FPV co-benefits. This consisted of identifying FPV research relevant to cobenefits and the energy water nexus. Once identified, we limited our analysis to reviewing recent (2014 through 2020), publicly available "review of FPV systems" papers published in English to help develop a list of claimed co-benefits and to identify additional information sources. Search terms including "floating PV", "floating photovoltaics", "floating solar" and "FPV" were used in Google Scholar and DuckDuckGo. Both scholarly and news articles were initially screened for relevance, and then the highlighted co-benefits and data were recorded, and citations explored. Once gaps in the co-benefit data support were identified, the previous search terms were combined with co-benefit relevant terms, such as "algae", and "water quality" to attempt to find empirical evidence beyond the sources cited. In total, 45 articles were reviewed in detail.

Following this broad literature survey, for each co-benefit cited in the literature, we reviewed the sources to identify whether these were based on theoretical data, empirical field data, or other sources, as shown in Figure 3. These co-benefits were then categorized as:

1. Empirically validated $(+)$ where papers provided empirical field data from existing FPV installations.

2. Theoretically validated $(\mathrm{T})$ where mention of a co-benefit was supported by modeling analysis but no empirical field data. 
3. Unclear or understudied (0) where mention of a co-benefit was supported by a selfciting data sources or no data or citation.

Where a non-FPV source was cited to validate a co-benefit, we noted the subject matter context of that source (e.g., benchtop biology study of algae in support of certain FPV ecological co-benefits).
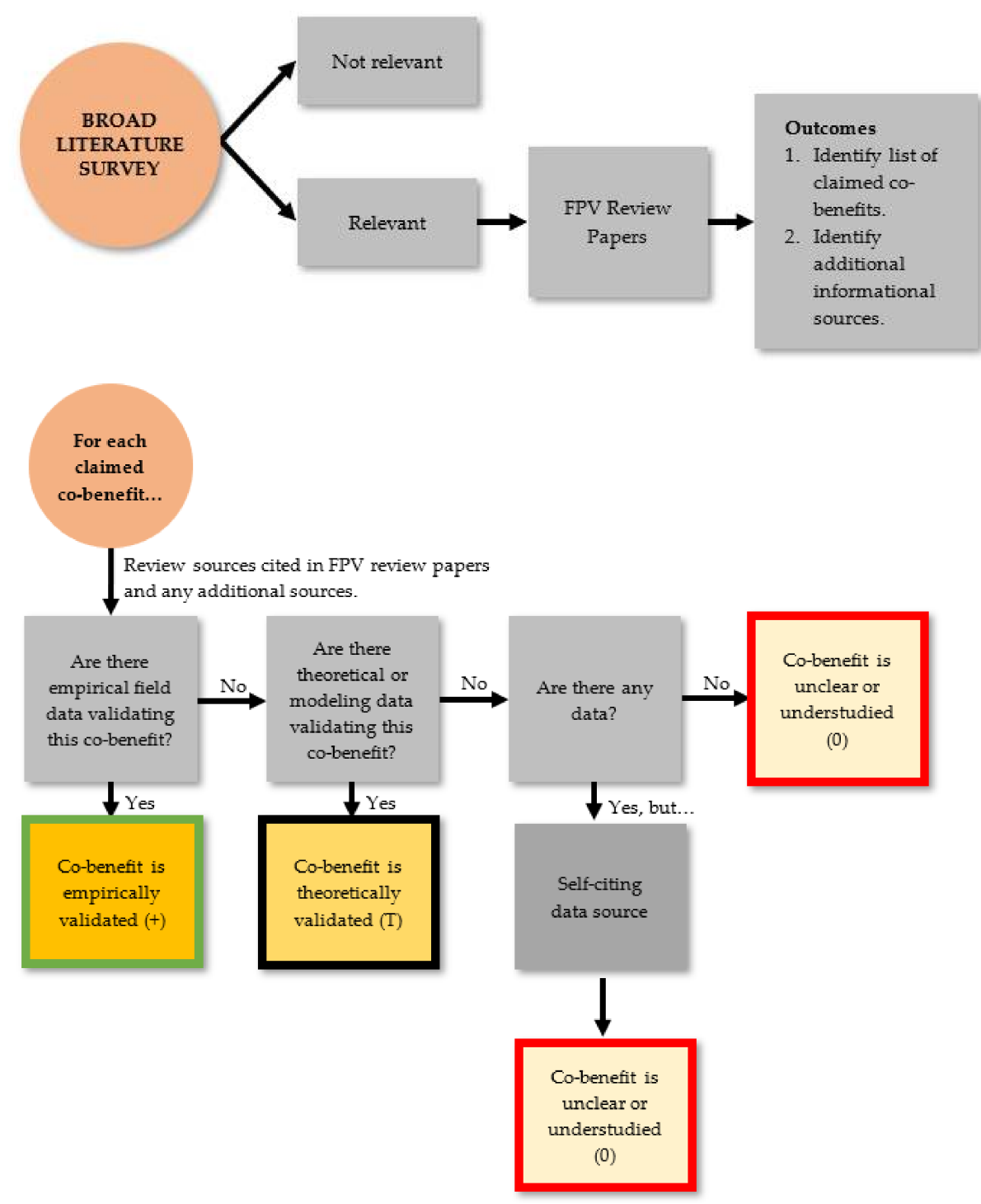

Figure 3. Overview of literature review methodology to (top) identify list of claimed of co-benefits and (bottom) co-benefit categorization.

\section{Results}

Table 2 presents a summary of our results from mapping each of the reviewed articles, data, and corresponding sources to each suggested co-benefit. The table lists co-benefits segmented by type and FPV system type (stand-alone or hybridized), with a designation of "Empirically confirmed $(+)$ ", "Theoretical (T)" or "Unclear or Understudied (0)" The table also provides citations and lists available values for the empirically confirmed co-benefits. Overall, our results revealed that most power generation and cost-related co-benefits of FPV systems are supported by empirical data; however, further research and empirical evidence are needed to validate several water-related and land-related co-benefits. 
Table 2. Co-benefit claims of FPV systems—-broken down by co-benefit type and FPV system type.

\begin{tabular}{|c|c|c|c|c|}
\hline Co-Benefit & FPV & FPV-Hydropower Hybrid & Values Reported & References \\
\hline \multicolumn{5}{|l|}{ Site-specific Power Generation } \\
\hline $\begin{array}{c}\text { Increased panel efficiency (lower } \\
\text { operating temperature) }\end{array}$ & + & $\mathrm{T}^{*}$ & $5-11 \%,>5^{\circ} \mathrm{C}$ & [61-65] \\
\hline Pack PV panels more densely & + & + & $8^{\circ}$ tilt for density ** & {$[64,66,67]$} \\
\hline Reduced shading & + & + & & {$[34,61,68]$} \\
\hline \multicolumn{5}{|l|}{ Water } \\
\hline Reduced evaporation & $\mathrm{T}$ & $\mathrm{T}$ & $\begin{array}{l}50 \%, 70 \%,>90 \% \\
680-1850 \mathrm{~mm} / \mathrm{yr}\end{array}$ & $\begin{array}{c}{[28,33-35,37-} \\
39,50,55,61,63,64,67,69-71]\end{array}$ \\
\hline $\begin{array}{l}\text { Reduced algae growth/improved } \\
\text { water quality }\end{array}$ & $\mathrm{T}$ & 0 & & {$[33-35,37,69,71-73]$} \\
\hline Lower water temperature & 0 & 0 & & {$[35,69]$} \\
\hline Power during drought & 0 & 0 & & {$[31,69,74]$} \\
\hline Reduced wave formation & 0 & 0 & & {$[35,37,67]$} \\
\hline \multicolumn{5}{|l|}{ Land } \\
\hline $\begin{array}{l}\text { Reduced land use/repurposed } \\
\text { bad land }\end{array}$ & + & $\mathrm{T}^{*}$ & $\begin{array}{l}\text { Land sparing ration of } 2.7: 1 \mathrm{~m} 2 \\
\text { (i.e., land required for } \\
\text { land-based PV system compared } \\
\text { to similar sized FPV system) }\end{array}$ & {$[28,33-35,51,64]$} \\
\hline $\begin{array}{c}\text { Location near } \\
\text { demand/population centers }\end{array}$ & $\mathrm{T}$ & $\mathrm{T}$ & & {$[28,33,34,64]$} \\
\hline \multicolumn{5}{|l|}{ Cost and other } \\
\hline Ease of installation & + & + & $1.2+1.7 \mathrm{MWp}$ installed $<1$ year & {$[34,75,76]$} \\
\hline Reduced site preparation & $\mathrm{T}$ & $\mathrm{T}$ & & {$[31,34,35]$} \\
\hline Modularity & + & + & & {$[34,35,37]$} \\
\hline Extends system life & 0 & 0 & & {$[40,69]$} \\
\hline \multicolumn{5}{|l|}{ Hybrid with hydroelectric dam } \\
\hline $\begin{array}{l}\text { Use existing electrical } \\
\text { transmission infrastructure }\end{array}$ & & $\mathrm{T}$ & & {$[31,34,44-48,61,77,78]$} \\
\hline Reduced curtailment & & $\mathrm{T}$ & & {$[31,34,44-48,61,77,78]$} \\
\hline Improved power quality & & $\mathrm{T}$ & & {$[31,34,44-48,61,77,78]$} \\
\hline
\end{tabular}

* This co-benefit was categorized as theoretical for hybrid systems because even though the same trend should be observed in both standalone and hybrid systems, empirical data from a hybrid installation had not yet been published as of this review. ${ }^{* *}$ This may not be the optimal tilt for energy production at a given latitude or for self-cleaning.

\section{Discussion}

This section discusses how the co-benefits of both the stand-alone and hybrid FPV systems reviewed in Table 2 demonstrate strong potential to meet the increasing demand for renewable energy sources while balancing the competing needs for water and land.

\subsection{Site-Specific Power Generation Co-Benefits}

The most widely documented and empirically supported benefit is increased panel efficiency leading to increased power production compared with a land-based PV system. For pontoon systems allowing air circulation behind the panel, an average $5-11 \%$ increase in power production has been reported in California (U.S.), Italy, Spain, and other locations [35,61-63,65]. This increase in panel efficiency is directly related to the reduced operating temperature of the panel, a well-documented benefit of siting the PV system on a water body [62,79]. The operating temperature is lower because of the water and air circulation below the $\mathrm{PV}$ panels on the pontoons. The extent of panel efficiency improvements varies based on pontoon design and climactic zone; for example, a more humid environment has less evaporative cooling, which would result in fewer efficiency benefits [60,61]. 


\subsection{Water-Related Co-Benefits}

Reduced evaporation is one of the most common benefit claims. One of the largest FPV installers, Ciel et Terre, claims reduced evaporation from their FPV installations but does not attempt to quantify it [35]. In a proposal to the Colorado River Basin Water Supply and Demand study, SPG Solar claimed a 70\% evaporation reduction based on their installation at Far Niente Winery. Supporting data were not available, and correspondence with Far Niente indicates no ability to measure evaporation reduction [69,80]; however, this installation covers most of the available water body surface area, suggesting that the evaporation calculations are partly based on water body area coverage. Sanchez et al. [50] use a geospatial estimation of the water loss caused by evaporation in Africa's existing hydropower reservoirs [15] to estimate additional potential hydroelectricity generation as a result of the water savings from covering the reservoirs with FPV. A similar approach was applied to quantify the evaporation savings of an FPV prototype in Alicante, Spain. Santafé et al. [55] installed a $300 \mathrm{~kW}$ FPV system test bed over an irrigation water reservoir, which covered $4490 \mathrm{~m}^{2}$, to measure evaporation savings and power generation and observed $5000 \mathrm{~m}^{3}$ of water savings per year because of avoided evaporation. Hoffacker et al. [28] applied the water savings-to-panel ratio from the Santafé study to a study of California's Central Valley and estimated that FPV systems could save $0.12 \mathrm{~km}^{3}$ of water per year. Most commonly, however, an Australian study of different evaporation reduction methods is cited as a proxy for FPV evaporation reduction [71], but empirical field data of reduced evaporation from an FPV installation were unavailable in the literature examined. The Solar Energy Research Institute of Singapore describes research in reduced water evaporation as "ongoing" [70].

Although there is no empirical evidence supporting this claim, several theoretical modeling studies have been conducted to demonstrate the evaporation reduction potential of FPV systems $[33,34,39,67,69,81,82]$. Further, several studies have conducted benchscale tests to validate claims of evaporation reduction. Zhang et al. [83] performed a bench-top evaporation test with a solar simulator, an organic PV cell, and a water-filled glass container and found a $24-35 \%$ evaporation reduction compared to an identical uncovered container of water. Taboada et al. [84] compared the evaporation potential of two identical preheated copper mine ponds with high-density polyethylene pontoons and PV covering $95 \%$ of the water area of one pond and the other pond left uncovered. Measurements during an 8-month time span showed $90 \%$ water savings in the FPVcovered pond compared to the uncovered pond [84]. As noted by Liber et al. [85], most of these evaporation studies use at least one of the following approaches: (1) using general evaporative models to predict specific evaporative savings for FPV systems, (2) installing a small-scale floating shade cover, (3) using traditional pan evaporative methods, and (4) using suspended shade cloth covers as a proxy for FPV system coverage. Based on some shortcomings of these methods' abilities to measure the empirical evaporation from FPV installations, the authors recommend using site-specific evaporation models to estimate potential evaporation savings [85]. Given that evaporation reduction is one of the primary cited co-benefits of FPV systems and that it could increase water availability for other uses, this is a critical information gap that should be addressed with further research.

Other water-related co-benefits claimed in the literature include improved water quality and reduced algae growth [34-39,69,82]; however, only one theoretical study on the potential ecological impacts of FPV systems has been published. Haas et al. [73] assessed the impact of FPV modules on the water quality of a hydropower reservoir by simulating total chlorophyll-a levels as a proxy for biomass (algal) growth and found that algal bloom was avoided when FPV modules covered $40-60 \%$ of the reservoir. Except for this modeling study, we were unable to validate other reports about water quality impacts. The primary citations for reduced algal growth are a book on growth rates of algae under differing intensities of ultraviolet (UV) light and an Australian study of various evaporation reduction technologies, neither of which have conclusive data on algal growth $[71,72]$. The Far Niente Winery anecdotally reported no impact on algae blooms, although the pond is used for discharge from cleaning wine equipment and this could 
affect algal growth [80]. As with the evaporation reduction potential, we found no available empirical data from FPV installations to support the claim that FPV reduces algal growth or improves water quality. A critical first step in addressing this gap is to collect various water quality measurements (such as chloride, $\mathrm{pH}$, and chlorophyll levels) and monitor general system performance [85].

\subsection{Land Use-Related Co-Benefits}

One of the most validated co-benefits of FPV systems is reduced land usage. In regions with land constraints or high land costs, FPV systems can support expanded PV installation, which was previously prohibitively expensive. Quantitative analysis in this research area is still growing; however, Liber et al. [85] conducted an initial theoretical analysis on the trade-offs between land use savings and power generation efficiency in FPV systems compared to land-based PV systems. The results indicate that FPV systems have a higher PV panel packing density, which allows more PV capacity to be installed for a given surface area; however, because land-based PV systems are typically installed at optimal tilt angles, among other factors, they could have a slightly higher power generation efficiency (that is, they have a higher megawatt-hour per megawatt of PV capacity installed). Cagle et al. [51] also recently published an empirical study that proposed three metrics to assess the land and water use efficiency of FPV systems at four installations in the United States: the land sparing ratio, water surface use efficiency, and water surface transformation. In many cases, despite the additional cost of the floatation system, the reduced cost of land acquisition and preparation results is a significant cost benefit to the FPV system, translating into as much as $26 \%$ lower development costs than ground-mounted PV [31,34,48,86].

\subsection{Cost and Installation Co-Benefits}

The FPV array can be assembled on land and simply towed out into the water. In Japan, a pair of FPV systems on lakes Nishihira (1.7 MWp) and Higashihira (1.2 MWp) were assembled, installed, and brought online in one year [75,76]. Depending on the transformer placement and anchoring systems, concrete use is also reduced or eliminated. Generalizing such installation benefits, however, might not be advisable because FPV installation timelines can vary widely because of different jurisdictional processes, site geography, and other factors.

\subsection{FPV-Hydropower Hybrid-Related Co-Benefits}

An emerging application of FPV systems is pairing the system with a hydropower reservoir, which could enable several additional co-benefits. These include power system optimization benefits, such as increased utilization of existing transmission infrastructure, reduced curtailment, improved power "quality" (such as smoothing of PV generation on both a minute-to-minute and hourly timescale, time-shifting, and seasonal compensation); and environmental benefits, such as water savings from reduced hydropower operation $[34,44,46,48,49,77]$. Although there are no publicly available empirical data from FPV-hydropower hybrid systems supporting these claims, several modeling studies have made a strong case for these co-benefits if the hybrid systems are planned and executed well. The Longyangxia Dam PV-hydropower hybrid system - which is not an FPV system but pairs hydropower generation with a nearby land-based PV power plant-successfully demonstrates some of these co-benefits [47,78]. Additionally, Liu et al. [45] modeled an FPV-hydropower hybrid system; the results indicate that this hybrid system could provide land use savings and evaporation savings as well as increased generation without reducing system reliability.

Regions such as the desert southwest in the United States and some countries in Southeast Asia could benefit from the addition of FPV to existing hydropower infrastructure to conserve water resources through reduced evaporation and generation diversification, ultimately easing stresses on limited water resources. Policy and planning considerations that ensure that existing or new hydropower deployment consider the costs and 
benefits of diversification with FPV, or other hybrid options, could ensure that power systems in these regions can reliably meet demand while also addressing these EWF system pressures. Ensuring that new hydropower or existing retrofits require quick-ramping or reactive turbine technologies could also help to future-proof these systems and allow for FPV hybridization [78].

\subsection{Reliability, Degradation, and Environmental Impact}

System lifetime-which determines FPV system cost-effectiveness-depends on a variety of factors, including the rate of panel and pontoon degradation. Plastic is known to degrade both under UV light and mechanical stress, and it can usually be mitigated by additives, such as UV absorbers. Lifetime panel and pontoon degradation, $\mathrm{O}$ and $\mathrm{M}$ costs, and water quality metrics during the lifetime of the FPV system are critical performance considerations for potential investors.

Typical ground-mounted PV manufacturers offer warranties from 10 to 12 years (and up to 25 years, in some cases) for PV modules and 10-year equipment warranties for PV inverters, as well as limited performance warranties [87,88]. For FPV systems, an additional warranty is usually provided for the FPV floatation structure. Companies selling FPV floatation structures typically offer a guarantee from 10 to 25 years for the pontoons [35,82]; however, limited data were found on warranties for pontoon performance, or data on PV panel or pontoon degradation, or how degradation of FPV systems compares to that of land-based PV systems.

Data from several FPV installations provide some insight into mechanical failures of floating systems $[37,61,64]$. For example, Liu et al. [61] detail mechanical damage caused by platform movement, including breaking joints, snapping electrical grounding connections, and struggles with wire management. The literature speculates that water and humidity are known to degrade PV system components, whereas in theory a reduced operating temperature might extend lifetime. Our review did not identify field data for plastic pontoon degradation or the impact of extreme weather events on systems.

Another area of uncertainty is the definition and scope of "environmental impacts" of FPV systems; however, environmental impacts as a co-benefit were omitted as a category in our analysis as there was a lack of agreement in the literature on the definition and scope of this term. There appear to be two interpretations: either degradation of the FPV system caused by environmental factors or the overall ecological damage (to aquatic ecosystems specifically), attributable to FPV installation and operation. In the latter, a clarification of terms would be helpful, as would field data on the effect of FPV systems on its host environment. Concerns over plastic degradation's effect on the host environment have led to the exploration of alternate pontoon materials, including coconut trees [89].

Figure 4 is a summary of the FPV co-benefits reviewed in this paper, highlighting which types are empirically confirmed, theoretically confirmed, or unclear.

\subsection{Policy and Planning Implications}

Consideration of EWF concerns by governments, utilities, and stakeholders in holistic policy and planning efforts will help to identify new solutions to address competing resource demands on EWF systems. FPV systems are one novel application that could help to ease these pressures; however, taking proactive steps will help to ensure successful deployment to realize these co-benefits. The co-benefits of stand-alone and hybridized FPV systems have the potential to appeal to the needs and values of communities and power systems worldwide.

Regions that have historically relied on hydropower generation and are now experiencing increased demands for power and water resources could prioritize hybrid FPV systems to diversify their fuel supplies and increase generation capacity, delaying the need for further hydropower resource development. Additionally, incentivizing FPV deployment on existing hydropower could help to increase performance while reducing the need to expand existing dams or construct new dams, ultimately avoiding land and 
water resource conflicts. Development of hybrid FPV systems should, however, account for climate change projections, the potential for water shortages, and impacts on reservoir water levels.

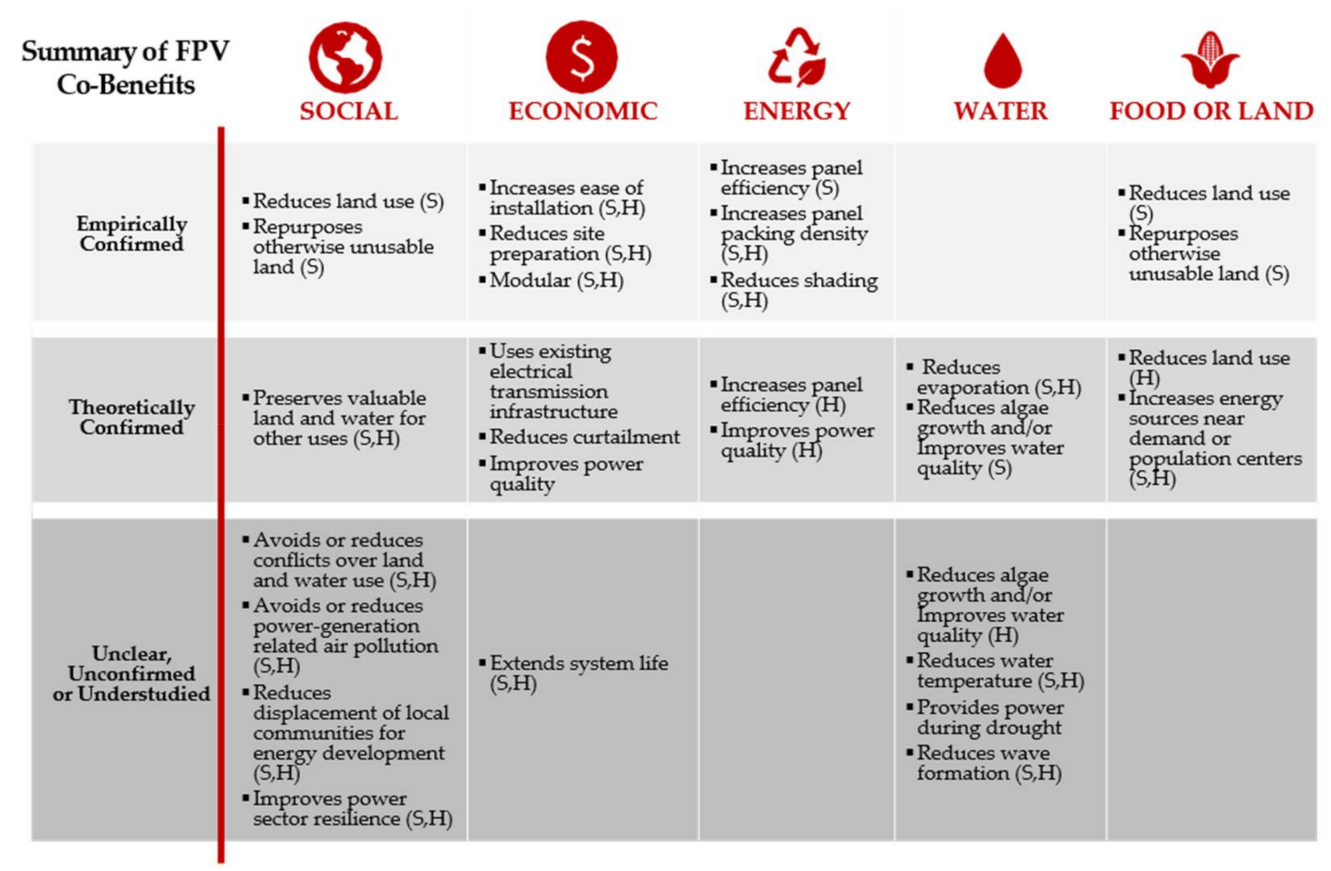

Figure 4. Summary of FPV co-benefits, $\mathrm{S}=$ stand-alone, $\mathrm{H}$ = hybridized FPV.

Land-constrained countries with competing land use needs for agriculture, energy generation, and housing might value the ability to site FPV in underused water bodies located close to demand centers, reducing land acquisition costs and impacts on food systems while providing low-cost generation (such as in Japan). Incentivizing the deployment of FPV systems in these areas could ease land use pressures while aligning with policies for the provision of affordable, carbon-free electricity.

Harmonizing the policies and regulations that affect FPV system siting on water bodies could be a first step in addressing these EWF nexus concerns while facilitating coordination across often disconnected government decision-making bodies. Clear, complementary incentives and restrictions for energy development, land use and agriculture, and water resource management could help reduce barriers and risks for FPV deployment while respecting the societal and ecosystem values of these systems. Overall, stand-alone FPV systems have been shown to minimize the energy, water, and land trade-offs associated with energy project development. The first FPV installation at Far Niente Winery was installed on their wastewater pond to spare valuable wine-growing land, and a recent study showed that deployment of FPV can spare 2.7 times the amount of land than would be used for ground-mounted PV systems [51]. Hybrid systems can also effectively leverage existing hydropower infrastructure and reduce-if not eliminate-land-related impacts. Because FPV is often sited on underused water bodies, it does not place additional demands on water resources that are needed for power generation, irrigation, drinking water, industry, and buildings, or the environment. There are also examples of FPV being effectively co-located with aquaculture [90,91].

Floating PV does have the potential to reduce the availability of water bodies for recreational, ecosystem, and aesthetic purposes. None of the FPV-EWF nexus literature reviewed in this study addressed the need to consider environmental justice and quantify broader social and sustainability co-benefits and impacts of FPV systems even though this is an area of increasing focus in the nexus literature [92]. Although broader social and political change may be needed to address the complex interrelationships of the EWF nexus, 
FPV systems show promise as a technology solution to address the competing demands for EWF systems.

\section{Conclusions}

FPV systems are a promising, new solar technology application with potentially numerous co-benefits in land-constrained and water-scarce regions. In this work, through a deep literature review, we identified and consolidated the empirically supported and unsupported co-benefits of FPV systems. Findings were summarized in a co-benefits table (Table 2) and in Figure 4, highlighting empirically confirmed co-benefits as well as gaps in the knowledge base. These identified research gaps, when addressed, could help justify the adoption of FPV systems, reduce the risk associated with developing FPV projects, and attract lower-cost capital and more investment in this new application of PV.

The empirically confirmed co-benefits include increased panel efficiency, reduced land usage, and ease of installation. FPV panels can produce 5-11\% more power than comparable-located land-based PV because evaporative cooling reduces the operating temperature of the panels. Similarly, our review confirmed that FPV systems use less land and can be installed more quickly, densely, and modularly with less shading than land-based PV systems. Other co-benefits have been theoretically studied or modeled but do not have supporting empirical data. These include reduced evaporation and the power system co-benefits of hydropower-FPV hybrids, such as improved power quality, reduced curtailment, and the use of existing infrastructure.

For several proposed FPV co-benefits, neither theoretical nor empirical evidence were found in our literature review. Water-related co-benefits are missing empirical evidence to support claims of reduced algal growth and improved water quality. Additionally, panel and pontoon degradation data were not found in publicly available literature, though field data may exist. Further, additional research is needed on the potential climate change impacts of stand-alone and hybrid FPV systems.

More data collection and research are needed on potential negative impacts of FPV systems. These might include changes in the ecosystem caused by shading and the introduction of floating structures, and the social and equity impacts of FPV systems competing for access to multipurpose waterways.

Empirical data from the 500+ stand-alone FPV installations globally could help validate these claimed co-benefits. FPV installations cover a wide variety of climatic zones and designs, which can help create a robust data set to monitor FPV system performance. Coordination and collaboration to carefully monitor water levels and algal growth would help to quantify the water saving potential of FPV, including enlisting experts in water systems to aid in these measurements. Monitoring could include plastic and metal degradation of the pontoons, wiring, and panels to better understand the environmental impacts of FPV systems on water bodies. The performance and resilience of FPV systems during storms is another open area for research. As with all solar applications, if they are well designed and properly installed, FPV systems can provide multiple synergistic co-benefits [38]; however, gaps in empirical data and more information on the potential adverse impacts of FPV need to be addressed to enable stakeholders to make well-informed and data-driven decisions.

Author Contributions: Conceptualization, all; methodology, N.L. and H.M.; validation, H.M. and S.G.; formal analysis, H.M.; investigation, S.G. and H.M.; resources, H.M. and S.G.; data curation, S.G. and H.M.; writing—original draft preparation, S.G. and H.M.; writing—review and editing, S.G., N.L., H.M., J.D. and A.W.; visualization, S.G. and H.M.; supervision, J.D.; project administration, J.D., N.L. and S.G.; funding acquisition, J.D. and A.W. All authors have read and agreed to the published version of the manuscript.

Funding: This research received no external funding. Heather Mirletz is a Ph.D. student funded by the Colorado School of Mines Advanced Energy Systems program.

Institutional Review Board Statement: Not applicable.

Informed Consent Statement: Not applicable. 


\section{Data Availability Statement: Not applicable.}

Acknowledgments: This work was authored and funded in part by the National Renewable Energy Laboratory, operated by Alliance for Sustainable Energy, LLC, for the U.S. Department of Energy (DOE) under Contract No. DE-AC36-08GO28308. The views expressed in the article do not necessarily represent the views of the DOE or the U.S. Government. The U.S. Government retains, and the publisher, by accepting the article for publication, acknowledges that the U.S. Government retains a nonexclusive, paid-up, irrevocable, worldwide license to publish or reproduce the published form of this work, or allow others to do so, for U.S. Government purposes. The authors are thankful for the reviews provided by Jordan Macknick and Juan Torres of NREL.

Conflicts of Interest: The authors declare no conflict of interest.

\section{References}

1. Chang, Y.; Li, G.; Yao, Y.; Zhang, L.; Yu, C. Quantifying the Water-Energy-Food Nexus: Current Status and Trends. Energies 2016, 9, 65. [CrossRef]

2. IRENA. Renewable Energy in the Water, Energy and Food Nexus. Available online: https://www.irena.org/- / media/Files/ IRENA/Agency/Publication/2015/IRENA_Water_Energy_Food_Nexus_2015.pdf (accessed on 22 June 2020).

3. Al-Saidi, M.; Elagib, N.A. Towards Understanding the Integrative Approach of the Water, Energy and Food Nexus. Sci. Total Environ. 2017, 574, 1131-1139. [CrossRef]

4. Semertzidis, T. Can Energy Systems Models Address the Resource Nexus? Energy Procedia 2015, 83, 279-288. [CrossRef]

5. Keskinen, M.; Guillaume, J.H.A.; Kattelus, M.; Porkka, M.; Räsänen, T.A.; Varis, O. The Water-Energy-Food Nexus and the Transboundary Context: Insights from Large Asian Rivers. Water 2016, 8, 193. [CrossRef]

6. WWAP (UNESCO World Water Assessment Programme). The United Nations World Water Development Report 2019: Leaving No One Behind; UNESCO: Paris, France, 2019.

7. Borowski, P.F.; Borowski, P.F. Nexus between Water, Energy, Food and Climate Change as Challenges Facing the Modern Global, European and Polish Economy. AIMS Geosci. 2020, 6, 397-421. [CrossRef]

8. Boretti, A.; Rosa, L. Reassessing the Projections of the World Water Development Report. NPJ Clean Water 2019, 2, 1-6. [CrossRef]

9. van Vliet, M.T.H.; Wiberg, D.; Leduc, S.; Riahi, K. Power-Generation System Vulnerability and Adaptation to Changes in Climate and Water Resources. Nature Clim. Chang. 2016, 6, 375-380. [CrossRef]

10. IEA. World Gross Electricity Production, by Source, 2018-Charts-Data \& Statistics. Available online: https:/ /www.iea.org/ data-and-statistics/charts/world-gross-electricity-production-by-source-2018 (accessed on 28 October 2020).

11. Miara, A.; Cohen, S.M.; Macknick, J.; Vörösmarty, C.J.; Corsi, F.; Sun, Y.; Tidwell, V.C.; Newmark, R.; Fekete, B.M. Climate-Water Adaptation for Future US Electricity Infrastructure. Environ. Sci. Technol. 2019, 53, 14029-14040. [CrossRef]

12. Sanders, K.T. Critical Review: Uncharted Waters? The Future of the Electricity-Water Nexus. Environ. Sci. Technol. 2015, 49, 51-66. [CrossRef] [PubMed]

13. Coffel, E.D.; Mankin, J.S. Thermal Power Generation Is Disadvantaged in a Warming World. Environ. Res. Lett. 2020. [CrossRef]

14. Zhao, G.; Gao, H.; Kao, S.-C. The Implications of Future Climate Change on the Blue Water Footprint of Hydropower in the Contiguous US. Environ. Res. Lett. 2021, 16, 034003. [CrossRef]

15. Gonzalez Sanchez, R.; Seliger, R.; Fahl, F.; De Felice, L.; Ouarda, T.B.M.J.; Farinosi, F. Freshwater Use of the Energy Sector in Africa. Appl. Energy 2020, 270, 115171. [CrossRef]

16. Putra, M.P.I.F.; Pradhan, P.; Kropp, J.P. A Systematic Analysis of Water-Energy-Food Security Nexus: A South Asian Case Study. Sci. Total Environ. 2020, 728, 138451. [CrossRef] [PubMed]

17. van Vliet, M.T.H.; Yearsley, J.R.; Ludwig, F.; Vögele, S.; Lettenmaier, D.P.; Kabat, P. Vulnerability of US and European Electricity Supply to Climate Change. Nat. Clim. Chang. 2012, 2, 676-681. [CrossRef]

18. Liao, X.; Hall, J.W.; Eyre, N. Water Use in China's Thermoelectric Power Sector. Glob. Environ. Chang. 2016, 41, 142-152. [CrossRef]

19. Bazmi, A. Nexus in South Asia: The Water, Food and Energy Nexus in Pakistan. Available online: https://www.water-energyfood.org/news/nexus-in-south-asia-the-water-food-and-energy-nexus-in-pakistan/ (accessed on 28 October 2020).

20. Harvey, M.; Pilgrim, S. The New Competition for Land: Food, Energy, and Climate Change. Food Policy 2011, 36, S40-S51. [CrossRef]

21. Kleemann, J.; Baysal, G.; Bulley, H.N.N.; Fürst, C. Assessing Driving Forces of Land Use and Land Cover Change by a MixedMethod Approach in North-Eastern Ghana, West Africa. J. Environ. Manag. 2017, 196, 411-442. [CrossRef] [PubMed]

22. van Ruijven, B.J.; De Cian, E.; Sue Wing, I. Amplification of Future Energy Demand Growth Due to Climate Change. Nat. Commun. 2019, 10, 2762. [CrossRef]

23. Trainor, A.M.; McDonald, R.I.; Fargione, J. Energy Sprawl Is the Largest Driver of Land Use Change in United States. PLoS ONE 2016, 11, e0162269. [CrossRef] [PubMed]

24. Tröndle, T. Supply-Side Options to Reduce Land Requirements of Fully Renewable Electricity in Europe. PLoS ONE 2020, 15, e0236958. [CrossRef]

25. Fritsche, U.R.; Berndes, G.; Cowie, A.L.; Dale, V.H.; Kline, K.L.; Johnson, F.X.; Langeveld, H.; Sharma, N.; Watson, H.; Woods, J. Global Land Outlook Working Paper: Energy and Land Use. United Nations Convention to Combat Desertification, International 
Renewable Energy Agency . Available online: https://knowledge.unccd.int/sites/default/files/2018-06/2.\%20Fritsche\%2Bet $\%$ 2Bal\%2B\%282017\%29\%2BEnergy\%2Band\%2BLand\%2BUse\%2B-\%2BGLO\%2Bpaper-corr.pdf (accessed on 7 December 2020).

26. Parish, E.S.; Kline, K.L.; Dale, V.H.; Efroymson, R.A.; McBride, A.C.; Johnson, T.L.; Hilliard, M.R.; Bielicki, J.M. Comparing Scales of Environmental Effects from Gasoline and Ethanol Production. Environ. Manag. 2013, 51, 307-338. [CrossRef] [PubMed]

27. Choi, C.S.; Siregar, I.Z.; Ravi, S. Reframing the Competition for Land between Food and Energy Production in Indonesia. In Land Cover and Land Use Change on Islands: Social \& Ecological Threats to Sustainability; Walsh, S.J., Riveros-Iregui, D., ArceNazario, J., Page, P.H., Eds.; Social and Ecological Interactions in the Galapagos Islands; Springer International Publishing: Cham, Switzerland, 2020; pp. 241-260. ISBN 978-3-030-43973-6.

28. Hoffacker, M.K.; Allen, M.F.; Hernandez, R.R. Land-Sparing Opportunities for Solar Energy Development in Agricultural Landscapes: A Case Study of the Great Central Valley, CA, United States. Environ. Sci. Technol. 2017, 51, 14472-14482. [CrossRef]

29. Ravi, S.; Macknick, J.; Lobell, D.; Field, C.; Ganesan, K.; Jain, R.; Elchinger, M.; Stoltenberg, B. Colocation Opportunities for Large Solar Infrastructures and Agriculture in Drylands. Appl. Energy 2016, 165, 383-392. [CrossRef]

30. U.S Environmental Protection Agency (EPA); NREL. Best Practices for Siting Solar Photovoltaics on Municipal Solid Waste Landfills. Available online: https:/ /www.epa.gov/sites/production/files/2015-03/documents/best_practices_siting_solar_ photovoltaic_final.pdf (accessed on 4 January 2021).

31. Cox, M. Floating Solar Landscape 2019; Wood Mackenzie Power \& Renewables. Available online: https://www.woodmac. com/our-expertise/focus / Power--Renewables/floating-solar-2019/?utm_source=gtmarticle\&utm_medium=web\&utm_ campaign=wmpr_floatingsolar (accessed on 11 December 2019).

32. Cazzaniga, R.; Rosa-Clot, M. The Booming of Floating PV. Sol. Energy 2020. [CrossRef]

33. Spencer, R.S.; Macknick, J.; Aznar, A.; Warren, A.; Reese, M.O. Floating Photovoltaic Systems: Assessing the Technical Potential of Photovoltaic Systems on Man-Made Water Bodies in the Continental United States. Environ. Sci. Technol. 2019, 53, 1680-1689. [CrossRef] [PubMed]

34. World Bank Group; ESMAP; SERIS. Where Sun Meets Water: Floating Solar Market Report-Executive Summary. The World Bank. pp. 1-24. Available online: http:/ / documents1.worldbank.org/curated/en/579941540407455831/pdf/Floating-SolarMarket-Report-Executive-Summary.pdf (accessed on 31 January 2019).

35. Ciel et Terre. Applications Compatible with Floating PV and Benefits. Ciel et Terre International. Available online: https: / /www.ciel-et-terre.net/floating-pv-applications / (accessed on 11 December 2019).

36. Trapani, K.; Redón Santafé, M. A Review of Floating Photovoltaic Installations: 2007-2013. Prog. Photovolt Res. Appl. 2015, $23,524-532$. [CrossRef]

37. Sahu, A.; Yadav, N.; Sudhakar, K. Floating Photovoltaic Power Plant: A Review. Renew. Sustain. Energy Rev. 2016, 66, 815-824. [CrossRef]

38. Hernandez, R.R.; Armstrong, A.; Burney, J.; Ryan, G.; Moore-O’Leary, K.; Diédhiou, I.; Grodsky, S.M.; Saul-Gershenz, L.; Davis, R.; Macknick, J.; et al. Techno-Ecological Synergies of Solar Energy for Global Sustainability. Nat. Sustain. 2019, 2, 560-568. [CrossRef]

39. Rosa-Clot, M.; Tina, G.M.; Nizetic, S. Floating Photovoltaic Plants and Wastewater Basins: An Australian Project. Energy Procedia 2017, 134, 664-674. [CrossRef]

40. Chandran, R. In Land-Scarce Southeast Asia, Solar Panels Float on Water. Available online: http://news.trust.org/item/201902 08102615-bye4f/ (accessed on 30 April 2019).

41. Pringle, A.M.; Handler, R.M.; Pearce, J.M. Aquavoltaics: Synergies for Dual Use of Water Area for Solar Photovoltaic Electricity Generation and Aquaculture. Renew. Sustain. Energy Rev. 2017, 80, 572-584. [CrossRef]

42. Floating Solar. Benefits of Floating Solar. Available online: https://www.floatingsolar.co.za/benefits/ (accessed on 7 December 2020).

43. Ranjbaran, P.; Yousefi, H.; Gharehpetian, G.B.; Astaraei, F.R. A Review on Floating Photovoltaic (FPV) Power Generation Units. Renew. Sustain. Energy Rev. 2019, 110, 332-347. [CrossRef]

44. Farfan, J.; Breyer, C. Combining Floating Solar Photovoltaic Power Plants and Hydropower Reservoirs: A Virtual Battery of Great Global Potential. Energy Procedia 2018, 155, 403-411. [CrossRef]

45. Liu, L.; Sun, Q.; Li, H.; Yin, H.; Ren, X.; Wennersten, R. Evaluating the Benefits of Integrating Floating Photovoltaic and Pumped Storage Power System. Energy Convers. Manag. 2019, 194, 173-185. [CrossRef]

46. An, Y.; Fang, W.; Ming, B.; Huang, Q. Theories and Methodology of Complementary Hydro/Photovoltaic Operation: Applications to Short-Term Scheduling. J. Renew. Sustain. Energy 2015, 7, 063133. [CrossRef]

47. Ming, B.; Liu, P.; Cheng, L.; Zhou, Y.; Wang, X. Optimal Daily Generation Scheduling of Large Hydro-Photovoltaic Hybrid Power Plants. Energy Convers. Manag. 2018, 171, 528-540. [CrossRef]

48. Cazzaniga, R.; Rosa-Clot, M.; Rosa-Clot, P.; Tina, G.M. Integration of PV Floating with Hydroelectric Power Plants. Heliyon 2019, 5, e01918. [CrossRef]

49. Lee, N.; Grunwald, U.; Rosenlieb, E.; Mirletz, H.; Aznar, A.; Spencer, R.; Cox, S. Hybrid Floating Solar Photovoltaics-Hydropower Systems: Benefits and Global Assessment of Technical Potential. Renew. Energy 2020, 162, 1415-1427. [CrossRef]

50. Gonzalez Sanchez, R.; Kougias, I.; Moner-Girona, M.; Fahl, F.; Jäger-Waldau, A. Assessment of Floating Solar Photovoltaics Potential in Existing Hydropower Reservoirs in Africa. Renew. Energy 2021, 169, 687-699. [CrossRef] 
51. Cagle, A.E.; Armstrong, A.; Exley, G.; Grodsky, S.M.; Macknick, J.; Sherwin, J.; Hernandez, R.R. The Land Sparing, Water Surface Use Efficiency, and Water Surface Transformation of Floating Photovoltaic Solar Energy Installations. Sustainability 2020, $12,8154$. [CrossRef]

52. Campana, P.E.; Wästhage, L.; Nookuea, W.; Tan, Y.; Yan, J. Optimization and Assessment of Floating and Floating-Tracking PV Systems Integrated in on- and off-Grid Hybrid Energy Systems. Sol. Energy 2019, 177, 782-795. [CrossRef]

53. Gamarra, C.; Ronk, J.J. Floating Solar: An Emerging Opportunity at the Energy-Water Nexus. Tex. Water J. 2019, $10,32-45$.

54. Hernandez, R.R.; Easter, S.B.; Murphy-Mariscal, M.L.; Maestre, F.T.; Tavassoli, M.; Allen, E.B.; Barrows, C.W.; Belnap, J.; Ochoa-Hueso, R.; Ravi, S.; et al. Environmental Impacts of Utility-Scale Solar Energy. Renew. Sustain. Energy Rev. 2014, 29, 766-779. [CrossRef]

55. Santafé, M.R.; Ferrer Gisbert, P.S.; Sánchez Romero, F.J.; Torregrosa Soler, J.B.; Ferrán Gozálvez, J.J.; Ferrer Gisbert, C.M. Implementation of a Photovoltaic Floating Cover for Irrigation Reservoirs. J. Clean. Prod. 2014, 66, 568-570. [CrossRef]

56. Sulaeman, S.; Brown, E.; Quispe-Abad, R.; Müller, N. Floating PV System as an Alternative Pathway to the Amazon Dam Underproduction. Renew. Sustain. Energy Rev. 2021, 135, 110082. [CrossRef]

57. Zhou, Y.; Chang, F.-J.; Chang, L.-C.; Lee, W.-D.; Huang, A.; Xu, C.-Y.; Guo, S. An Advanced Complementary Scheme of Floating Photovoltaic and Hydropower Generation Flourishing Water-Food-Energy Nexus Synergies. Appl. Energy 2020, 275. [CrossRef]

58. Reindl, D.T.; Paton, C. Where Sun Meet Water: Global Market Status; Project Database and Economics; Solar Energy Research Institute of Singapore, National University of Singapore: Singapore, 2020.

59. PV Magazine. Floating Solar Nearing Price Parity with Land-Based US Solar. Available online: https://www.pv-magazine.com/ 2020/10/07 / floating-solar-nearing-price-parity-with-land-based-us-solar / (accessed on 10 December 2020).

60. Esteves Galdino, M.A.; de Almeida Olivieri, M.M. Some Remarks about the Deployment of Floating PV Systems in Brazil. J. Electr. Eng. 2017, 5, 10-19.

61. Liu, H.; Krishna, V.; Lun Leung, J.; Reindl, T.; Zhao, L. Field Experience and Performance Analysis of Floating PV Technologies in the Tropics. Prog. Photovolt. Res. Appl. 2018, 26, 957-967. [CrossRef]

62. Cazzaniga, R.; Rosa-Clot, M.; Rosa-Clot, P.; Tina, G.M. Floating Tracking Cooling Concentrating (FTCC) Systems. In Proceedings of the 2012 38th IEEE Photovoltaic Specialists Conference, Austin, TX, USA, 3-8 June 2012; pp. 514-519.

63. Ferrer-Gisbert, C.; Ferrán-Gozálvez, J.J.; Redón-Santafé, M.; Ferrer-Gisbert, P.; Sánchez-Romero, F.J.; Torregrosa-Soler, J.B. A New Photovoltaic Floating Cover System for Water Reservoirs. Renew. Energy 2013, 60, 63-70. [CrossRef]

64. Trapani, K.; Millar, D.L. Proposing Offshore Photovoltaic (PV) Technology to the Energy Mix of the Maltese Islands. Energy Convers. Manag. 2013, 67, 18-26. [CrossRef]

65. Choi, Y.-K.; Lee, N.-H.; Kim, K.-J. Empirical Research on the Efficiency of Floating PV Systems Compared with Overland PV Systems. In Proceedings of the 3rd International Conference on Circuits, Control, Communication, Electricity, Electronics, Energy, System, Signal and Simulation, Guam, USA, 18-20 July 2013; Volume 25, pp. 284-289.

66. Redón Santafé, M.; Torregrosa Soler, J.B.; Sánchez Romero, F.J.; Ferrer Gisbert, P.S.; Ferrán Gozálvez, J.J.; Ferrer Gisbert, C.M. Theoretical and Experimental Analysis of a Floating Photovoltaic Cover for Water Irrigation Reservoirs. Energy 2014, 67, 246-255. [CrossRef]

67. Perez, M.; Perez, R.; Ferguson, C.R.; Schlemmer, J. Deploying Effectively Dispatchable PV on Reservoirs: Comparing Floating PV to Other Renewable Technologies. Sol. Energy 2018, 837-847. [CrossRef]

68. Smyth, M.; Russell, J.; Milanowski, T. Springer Science \& Business Media: Berlin/Heidelberg, Germany, 2011; ISBN 978-0-85729844-7. Available online: https:/ / www.springer.com/gp/book/9780857298430 (accessed on 12 December 2019).

69. SPG Solar. Evaporation Reduction via Floatovoltaics Systems; Colorado River Basin, USBR. Available online: https://www.usbr. gov/lc/region/programs/crbstudy/1_Evaporation_Reduction_via_Floatovoltaics_Systems.pdf (accessed on 9 October 2019).

70. World Bank Group; Energy Sector Management Assistance Program (ESMAP); Solar Energy Research Institute of Singapore (SERIS). Where Sun Meets Water: Floating Solar Handbook for Practitioners. Available online: http: / documents.worldbank.org/ curated/en/418961572293438109/pdf/Where-Sun-Meets-Water-Floating-Solar-Handbook-for-Practitioners.pdf (accessed on 21 November 2019).

71. Craig, I.; Green, A.; Scobie, M.; Schmidt, E. Controlling Evaporation Loss from Water Storages; University of Southern Queensland, National Centre for Engineering in Agriculture: Toowoomba, Qld, Australia, 2005.

72. Alam, M.Z.B.; Ohgaki, S. Evaluation of UV-radiation and its residual effect for algal growth control. In Advances in Water and Wastewater Treatment Technology; Matsuo, T., Hanaki, K., Takizawa, S., Satoh, H., Eds.; Elsevier Science B.V.: Amsterdam, The Netherlands, 2001; pp. 109-117. ISBN 978-0-444-50563-7.

73. Haas, J.; Khalighi, J.; de la Fuente, A.; Gerbersdorf, S.U.; Nowak, W.; Chen, P.-J. Floating Photovoltaic Plants: Ecological Impacts versus Hydropower Operation Flexibility. Energy Convers. Manag. 2020, 206, 112414. [CrossRef]

74. Silvério, N.M.; Barros, R.M.; Tiago Filho, G.L.; Redón-Santafé, M.; dos Santos, I.F.S.; de Mello Valério, V.E. Use of Floating PV Plants for Coordinated Operation with Hydropower Plants: Case Study of the Hydroelectric Plants of the São Francisco River Basin. Energy Convers. Manag. 2018, 171, 339-349. [CrossRef]

75. Peschel, T. Floating Photovoltaic Installations in Japan. Available online: https://www.sunwindenergy.com/photovoltaics/ floating-photovoltaic-installations-japan (accessed on 11 December 2019).

76. Mancheva, M. Kyocera, Century Tokyo Complete 2.9 MW of Japanese Floating PV. Available online: https:/ / renewablesnow. com/news/kyocera-century-tokyo-complete-29-mw-of-japanese-floating-pv-473131/ (accessed on 11 December 2019). 
77. Aghahosseini, A.; Bogdanov, D.; Breyer, C. A Techno-Economic Study of an Entirely Renewable Energy-Based Power Supply for North America for 2030 Conditions. Energies 2017, 10, 1171. [CrossRef]

78. Rogner, M. Case Study: Solar PV-Hydro Hybrid System at Longyangxia, China. Available online: https://www.hydropower. org/blog/case-study-solar-pv\%E2\%80\%93hydro-hybrid-system-at-longyangxia-china (accessed on 4 December 2020).

79. Majid, Z.A.A.; Ruslan, M.H.; Sopian, K.; Othman, M.Y.; Azmi, M.S.M. Study on Performance of 80 Watt Floating Photovoltaic Panel. J. Mech. Eng. Sci. 2014, 7, 1150-1156. [CrossRef]

80. Allen, G. Floating Solar at Far Niente, Correspondence with Winemaker. (Email exchange on 15 November 2019).

81. Chengaev, A.I. Reducing Evaporation at California Aqueduct by Using Floating Photovoltaic System; California State University: Sacramento, CA, USA, 2019.

82. Ibeke, M.; Miller, E.; Sarkisian, D.; Gold, J.; Johnson, S.; Wade, K. Floating Photovoltaics in California-Project Final Report I Tomkat. Available online: https: / / tomkat.stanford.edu/floating-photovoltaics-california-project-final-report (accessed on 7 March 2018).

83. Zhang, N.; Chen, G.; Xu, Y.; Xu, X.; Yu, L. Power Generation, Evaporation Mitigation, and Thermal Insulation of Semitransparent Polymer Solar Cells: A Potential for Floating Photovoltaic Applications. ACS Appl. Energy Mater. 2019, 2, 6060-6070. [CrossRef]

84. Taboada, M.E.; Cáceres, L.; Graber, T.A.; Galleguillos, H.R.; Cabeza, L.F.; Rojas, R. Solar Water Heating System and Photovoltaic Floating Cover to Reduce Evaporation: Experimental Results and Modeling. Renew. Energy 2017, 105, 601-615. [CrossRef]

85. Liber, W.; Bartle, C.; Spencer, R.S.; Macknick, J.; Cagle, A.E.; Lewis, T. Statewide Potential Study for the Implementation of Floating Solar Arrays. Ciel et Terre, National Renewable Energy Laboratory, Colorado Energy Office. Available online: https://drive. google.com/file/d/1PjrwsUeXygNyW7xBBvcZyxTRT8aB19N3/view? usp=drive_open\&usp=embed_facebook (accessed on 10 April 2020).

86. Pickerel, K. What to Consider When Installing a Floating Solar Array. Available online: https:/ / www.solarpowerworldonline. com/2016/06/consider-installing-floating-solar-array/ (accessed on 6 March 2018).

87. U.S. Department of Energy Office of Indian Energy. The Five-Step Development Process, Step 5: Project Operations and Maintenance. Available online: https:/ / www.energy.gov/sites/prod/files/2015/06/f23/7a\%20Step \%205\%20Project $\% 20$ Operations $\%$ 20and\%20Maintenance.pdf (accessed on 8 January 2021).

88. EnergySage. Solar Panel Warranties: What You Need to Know. Available online: https://news.energysage.com/shopping-solarpanels-pay-attention-to-solar-panels-warranty / (accessed on 8 January 2021).

89. Fauzan, N.; Yacob, M.E.; Mokhtar, M.N.; Hizam, H. Development of Coconut-Based Floating Structure for Stand-Alone Solar PV System in the Tropics. Acta Hortic. 2017, 1152, 95-100. [CrossRef]

90. Jones, J.S. Floating Solar Powers Seaweed Farming. In Smart Energy International. Available online: https://www.smart-energy. $\mathrm{com} /$ renewable-energy / floating-solar-powers-seaweed-farming/ (accessed on 4 April 2021).

91. Inhabit. Chinese Fishery Installs Immense Floating Solar Farm for Extra Income. Available online: https://inhabitat.com/ immense-floating-solar-farm-at-chinese-fishery-replaces-7-4-tons-of-coal/ (accessed on 4 April 2021).

92. Middleton, C.; Allouche, J.; Gyawali, D.; Allen, S. The Rise and Implications of the Water-Energy-Food Nexus in Southeast Asia through an Environmental Justice Lens. Water Altern. 2015, 8, 627-654. 